\title{
Las tramas del origen: el proyecto de identidad nacional en las novelas Ubirajara e Iracema, de José de Alencar*
}

\author{
Jaime Morales Quant ${ }^{1}$ \\ Universidad Rafael Núñez (Colombia)
}

\section{Resumen}

Ubirajara e Iracema, novelas de José Martiniano de Alencar (Fortaleza, 1829 - Río de Janeiro, 1877), son proyectos estéticopolíticos que aspiran a construir la identidad brasileña, mediante la articulación de mitos nacionales. Inspirados en el trabajo crítico de Lucía Sa (2009), consideramos que el escritor recurre a dos grandes operaciones, para llevar a cabo esta tarea. En la primera obra, Alencar efectúa una "humanización" de los habitantes originarios. Ya sea por su convergencia con principios éticos europeos y cristianos, o por su diferencia cultural (leída paradójicamente desde un lente occidentalizado), el indio aparece como "buen salvaje". Y en la segunda, el autor sugiere una colonización que, aunque no exenta de dolor, es ennoblecida por

\begin{abstract}
Ubirajara e Iracema, novels by José Martiniano de Alencar (Fortaleza, 1829 - Río de Janeiro, 1877), are aesthetic- politics projects that attempt to build the Brazilian identity by means of the articulation of national myths. Inspired by the work of the critic Lucía Sa (2009), we examine the work of this writer as one who uses two great artifacts to carry out his task. In the first novel, Alencar, "humanizes" the natives. This is; either for his convergence with ethical European and Christian principles, or for the cultural difference he found (paradoxically read from a western lens), where the indigenous character appears as "the good savage". And in the second one, when the author suggests that a colonization that, even though, is not, exempt of pain, is dignified
\end{abstract}

\footnotetext{
* "The storyline of the origin: the project of national identity in the novels Ubirajara and Iracema by José de Alencar"

Recibido: 2 de octubre de 2013 - Aprobrado: 10 de noviembre de 2013

${ }^{1}$ Profesional en Lingüística y Literatura de la Universidad de Cartagena. Candidato a Magíster en Literatura Española y Latinoamericana de la Universidad de Buenos Aires. Docente de la Universidad Rafael Nuñez. e-mail: jamoq22@yahoo.com
} 
la llegada del cristianismo y por la entrada del proyecto "civilizatorio blanco", con todas sus instituciones, con toda su historia y su "destino". De esta manera, si en Ubirajara, Alencar se preocupa por el origen precolonial, en Iracema plantea otra clase de comienzo: el que se fragua con el "arribo" de los portugueses.

Palabras clave: literatura brasileña, identidad nacional, indígena, colonización, cristianismo. by the arrival of Christianity and by the entrance of "white civilizing" project. This means, with all its institutions, with all its history and its "destiny". This way, if in Ubirajara, Alencar is preoccupied by the precolonial origin, in Iracema he proposes a different way to see the beginning: the one that occurs with the "arrival" of the Portuguese people.

Keywords: Brazilian literature, national identity, indigenous, colonization, christianism.

“[...] durante largos siglos las tierras de América se definen por ser colonia de [...] por eso ser americano supone siempre imágenes que se construyen a través de la adhesión a tres bloques de perspectivas: el de la mirada del hombre de la metrópoli, el de los habitantes nativos y el que problematiza las tensiones existentes entre los dos."

Valeria de Marco.

Las novelas Ubirajara e Iracema, de José de Alencar son proyectos estético-políticos que aspiran a construir la identidad brasileña, mediante la articulación de mitos nacionales. Inspirados en el ensayo crítico de Lucía Sa (2009), consideramos que el escritor recurre a dos grandes operaciones, para llevar a cabo esta tarea: a) en la primera obra, Alencar efectúa una "humanización" de los habitantes originarios. Ya sea por su convergencia con principios éticos europeos y cristianos, o por su diferencia cultural (leída paradójicamente desde un lente occidentalizado), el indio aparece como "buen salvaje". Con ello, el autor re-crea una memoria de las raíces. Tal como apunta Elvia Ribeiro Pereira (1996: 109), "estabelece seu projeto literário, tendo como pressuposto básico a invenção do pasado [...] uma biografia da nação"2.

Estos procesos de dignificación del indígena pretenden impugnar la imagen negativa que lo reduce a un abominable animal, centro

2 "Alencar establece su proyecto literario, teniendo como presupuesto básico la invención del pasado, una biografía de la nación” (La traducción es nuestra). 
de pura pulsión, figura ausente de racionalismo o religiosidad. La representación del indio permite, al mismo tiempo, erigir una identidad diferencial con respecto a otros países europeos y latinoamericanos; y promover/conservar valores que se destacarían en el aborigen, pero que, en efecto, interpelan a los ciudadanos de un país posible. Coincidimos con Valeria de Marco (1993) cuando asevera que:

\begin{abstract}
Alencar quería construir la memoria de la nación a través de imágenes que explicaran el país, que lo diferenciaran en relación con los demás, que alimentaran la imaginación de los brasileños creando sus señas de identidad [...] Alencar crea una interpretación del pasado en la que propone una compleja jerarquía de imágenes para forjar una historia, no del proceso vivido, sino de lo que debe quedar en la memoria. Constituye así parámetros éticos que podrían dirigir la construcción de la historia presente y futura (84-85.Las cursivas son nuestras).
\end{abstract}

b) En la segunda obra, el autor sugiere una colonización que, aunque no exenta de dolor, es ennoblecida por la llegada del cristianismo y la entrada del proyecto "civilizatorio blanco", con todas sus instituciones, historia y "destino". De modo que si en Ubirajara Alencar se preocupa por el origen precolonial, en Iracema plantea otra clase de comienzo: el que se produce con el "arribo" de los portugueses.

\title{
1. Climas históricos: entre el afuera y el adentro
}

Es preciso recurrir a un estrato explicativo con el objeto de entender la apuesta alencariana. Por un lado, conviene referirse al contexto político (ciertamente agitado, expectante); por el otro, al movimiento romántico. En cuanto al primero, Alencar escribe en el marco del período postindependentista, donde empiezan a forjarse los nacionalismos ${ }^{3}$. En ese entonces, las preguntas sobre la pertenencia a una comunidad se tornan ineludibles: ¿quiénes somos?, ¿cómo nos constituimos? Eliane Deckmann Fleck (2005) y Antonio Candido (1981) lo describen como un momento que requería la apelación o el diseño de referentes ideológicos encaminados a combatir el caos sociopolítico. La literatura podía comprometerse con la realidad concreta: "Peri, Ubirajara [...] brotam como respostas ao desejo ideal de heroísmo e pureza a que se apegava, a fim de poder acreditar em

\footnotetext{
${ }^{3}$ Seguimos a Silvia de Marco (1993: 84): "la obra de José de Alencar se inserta en ese debate político y cultural".
} 
si mesma, uma sociedade mal ajustada, e presa a lutas recentes de crescimento político [...]" (1981: 223) ${ }^{4}$.

A nivel estético, hay que pensar en lo discursos del romanticismo como elementos articuladores del concepto "identidad colectiva". Justamente, algunas variantes de la corriente artística aspiraban a conseguir una esencia unificadora, capaz de condensar el espíritu de los pueblos. Era necesario buscar o instaurar elementos que configuraran una brasileñeidad. Y justamente, Alencar "fixou um dos mais caros modelos da sensibilidade brasileira: o do índio ideal, elaborado por Gonçalves Dias, mas lançado por ele na própria vida cotidiana5." (Candido, 1981: 224). Como se presiente, esta necesidad de forjar la identidad grupal entraña una relación con flujos discursivos foráneos. Valeria de Marco (1993), por ejemplo, señala el estrecho nexo que tiene la obra del brasileño con la literatura europea. Según ella, el autor "Quería crear héroes y sus acciones majestuosas a semejanza de las naciones del occidente hegemónico donde cada país tenía también sus narrativas épicas y sus héroes civilizadores: El Cid, en España; Ricardo Corazón de León, en Inglaterra; Rolando, en Francia" (84).

En el contexto referido, también se destacarían los textos de Ferdinand Denis y Von Martius, quienes sobresalen como forjadores de un saber etnográfico (véase Carrizo, 2001). Y no menos relevante es el papel de las élites de Brasil, que se movilizaron a Francia e informaron sobre los movimientos contemporáneos; así como una serie de editores, libreros y periodistas interesados en esta red de información.

Después de la independencia de Portugal las relaciones
culturales con Francia se intensifican: por un lado, los
jóvenes van a estudiar a París; por el otro, editores, libreros y
periodistas franceses pasan a vivir en Rio, siguiendo el camino
abierto por intelectuales europeos que habían visitado el país
durante la permanencia de Dom Joao. De Francia -metrópoli
cultural de ese momento- llegaba el ideario romántico, sea a
través de autores franceses, sea a través de obras y revistas
redactadas por brasileños en el París. Estos libros y periódicos

4 "Peri, Ubirajara brotan como respuestas a un deseo ideal de heroísmo y pureza a que se apegaba, a fin de poder creer en sí misma, una sociedad mal ajustada, y presa de luchas recientes relacionadas con el crecimiento político". (La traducción es nuestra).

5 “[...] fijó uno de los más caros modelos de la sensibilidad brasileña: el del indio ideal, elaborado por Gonçalves Dias, pero más lanzado por él en la propia vida cotidiana". (La traducción es nuestra). 
llegaban al puerto de Rio de Janeiro como paquetes listos para la venta (Marco, 1993: 81).

De acuerdo con Lucía Sa (2009), hay un conjunto de fuentes que alimentan el trabajo de investigación antropológica y literaria emprendido por José de Alencar, y permiten entrever su vínculo con viajeros y estudiosos, pero con respecto a los cuales el autor no tiene ninguna actitud pasiva. En otras palabras, acepta, reformula, critica y corrige tales fuentes:

Ellas son: Jean De Léry, Thévet, Gabriel Soares de Sueza, Gandavo, Hans Staden, Barloeus y Orellana en el siglo XVI; los padres Claude d`Abeville e Ives dÈureux en el siglo XVII; y Ferdinand Dénis, Humbolsdt, y Southey en los siglos XVIII y XIX (11).

Otros estudiosos señalan conexiones con escritores franceses como René de Chateaubriand, o estadounidenses como James Fenimore Cooper. Por esto, acogemos la exhortación de María Teresa Gramuglio (2004) de ensanchar los horizontes relacionales a la hora de hacer comparaciones entre artefactos literarios; sobre todo cuando señala que es preciso rebasar la tradicional dupla "literatura nacional/extranjera", para pasar a discurrir sobre una red de enlaces más dinámica y amplia: nacional, latinoamericana, norteamericana, europea. Atendiendo a esta diversidad de influencias, SánchezConejero (s/f) afirma sobre Iracema:

Antônio Soares Amora ha resaltado [...] la influencia del romance Átala. El crítico subraya en A Literatura Brasileira. El Romantismo cómo "de las fuentes literarias de Iracema, la más influyente en el espíritu de Alencar fue, sabidamente, Átala". [...] Naomi Lindstrom señala, además de esta fuente, la "literatura nacional" de James Fenimore Cooper, que a su vez fue influido por obras como el poema "The Lady of the Lake" (1810) de Sir Walter Scout. Seguramente, Alencar tendría en mente los Leatherstocking Tales, con novelas como The Pioneers (1823) o The Last of the Mohicans (1826) (2).

En el prefacio de otra de sus obras, el propio Alencar reconoce la necesidad de nutrirse de repertorios culturales exteriores. Con ello no sólo se distancia de una posición ortodoxa nativista, sino que, al tiempo, jerarquiza civilizaciones, distinguiendo a las más "adelantadas". En este juego de posiciones, Brasil es concebido como sociedad naciente, dotada de una propensión natural a recibir influencias. 
[...] Alencar deixa isto claro no prefácio de Sonhos d'ouro: A importação contínua de ideais e costumes estranhos, que dia por dia nos trazem todos os povos do mundo, devem por força de comover uma sociedade nascente, naturalmente inclinada a receber o influxo de mais adiantada civilização [...] e a pouco e pouco vão diluindo-se para infundir-se n` alma da pátria adotiva, e formar a nova grande nacionalidade brasileira (Dekcmann, 2005: 204) ${ }^{6}$.

De una u otra manera, tales ideas permiten "mapear" las raíces de aquellos principios morales que los Estados, los artistas y los sujetos sociales buscan promover como correctos. Con todo, las anteriores consideraciones trazan el carácter dominante de la civilización europea. Y sin embargo, ayudan a visualizar que los procesos de intercambio cultural comportan niveles de reajustes o transformaciones.

\section{Humanización del pasado primigenio o de las buenas raíces nacionales $^{7}$}

Es sabido que el tema de la exaltación del indio se insertó en las necesidades identitarias latinoamericanas del siglo XIX, pero no dejaba de ser problemático. El proyecto de Alencar, como ya se adelantaba, tuvo que hacerle frente a las degradaciones que otros esgrimieron contra las culturas aborígenes. Es por ello que concibió su trabajo como escenario de lucha discursiva: "Fue en brasil donde se ha desarrollado de parte de cierta gente una aversión hacia el elemento indígena de nuestra literatura, al punto de eliminarlo por completo. Contra esa extravagante pretensión presenta una nueva protesta el presente libro" (2009: 136) ${ }^{8}$.

Unas palabras del apartado titulado "Advertencia al lector" contienen el tinte ideológico que la novela defenderá: “¿cómo admitir que bárbaros, brutos y caníbales, antes fieras que hombres, tal como nos retrataron a los indígenas, fuesen susceptibles de esos bríos

\footnotetext{
6 "Alencar deja esto claro en el prefacio de Sueños de oro: La importancia continua de ideales y costumbres extrañas, que día por día nos traen todos los pueblos del mundo, deben por fuerza conmover a una sociedad naciente, naturalmente inclinada a recibir el influjo de la más adelantada civilización [...] y una que poco a poco va diluyéndose para introducirse en el alma de una patria adoptiva, y formar una nueva gran nacionalidad brasileña". (La traducción es nuestra).

${ }^{7}$ Comenzaremos con Ubirajara que, aunque posterior a nivel cronológico, representa de un modo más cabal el proyecto de la gran épica nacional (Ribeiro Pereira, 1996). Por ello se vincula rápidamente con la información del apartado anterior.

${ }^{8}$ Todas las citas de Ubirajara serán extraídas de Alencar (2009).
} 
nativos que realzan la dignidad del rey de la creación?" (21). Estas exaltaciones/humanizaciones del indio estarán concretadas por distintos procedimientos discursivos. Ya lo veremos. Pero requieren, ante todo, de una autorepresentación del autor como sujeto provisto de saber. De hecho, su obra está acompañada de notas que evidencian el nexo con el "sujeto blanco" en términos epistémicos y morales. De acuerdo con Sa (2009), son "ellas las que dan al texto el elemento dramático que falta a la leyenda: el contacto con la cultura europea" (17). Esto se corrobora cuando exploramos las funciones que cumplen las anotaciones:

[...] explicaciones del vocabulario tupí, generalmente acompañadas de observaciones etimológicas; comentarios y aclaraciones respecto de las costumbres indígenas; observaciones respecto de las fuentes en que se basó (cronistas e historiadores); y finalmente, justificación referida a la utilización de ciertos elementos en detrimento de otros (Sa, 2009: 10).

A continuación, se intentará revelar un conjunto de reflexiones realizadas por Alencar, a partir de las cuales se constituye espiritualmente al indígena de la comunidad tupí 9 .

\subsection{Prácticas sexuales-amorosas}

La complejidad de las relaciones amorosas/sexuales es un escenario de análisis que sirve para legitimar la moralidad del indio. El autor se detiene en el matrimonio, el respeto a la fidelidad, la contención de la libido, la ponderación de la virginidad, para destacar la "pureza" espiritual de la cultura tupí. En cierto pasaje de la obra, Jandira, la virgen con la que piensa casarse Ubirajara antes de conocer a Araci, exalta sus propias cualidades como esposa incondicional:

[...] tu esposa te acompañará por todas partes, en la aldea, como en el campo de combate; ella cuidará de tu cabaña; preparará los más sabrosos manjares para su guerrero, y fabricará para él el vino que es el alma de la fiesta [...] su amor será la ventura de un guerrero valiente. Ubirajara no podría encontrar esposa más fiel [...] (45).

\footnotetext{
${ }^{9}$ La reivindicación del aborigen se concentra con frecuencia en el tupí. No obstante, en otros momentos, se expande de forma general hacia otras culturas indígenas que ocuparon el territorio donde se fundó Brasil. Por otro lado, cabe precisar que usaremos los plurales "tupís" o "tupíes" de forma indistinta.
} 
Lo anterior le hará decir al propio Alencar que se trata de una sociedad civilizada: "[...] ¿en qué sociedad civilizada se observa semejante respeto por la unión conyugal, al punto de no consentir que la mujer caída conserve el secreto de su falta y engañe al hombre que la busca para esposa?" (117). Otra práctica que le interesa al autor, por cuanto implica estima por la castidad y el compromiso, es el rito mediante el cual la madre de alguna joven en pubertad pone entre sus piernas una liga, a fin de señalar su estado virginal. La costumbre dictaba que si una muchacha era "desflorada" por alguien que no fuese su marido, debía romper dicha cinta indicando que ya había perdido su himen. De este modo, daba pruebas de la obediencia hacia el rito, y por supuesto, de su admirable honestidad. En este ámbito corporal va a ser igual de importante la concepción del casamiento basado en el amor y no en el desbordamiento lujurioso: "mi suposición se funda en el hecho de que se da entre estos pueblos un casamiento bien caracterizado y no simple coito" (122). Justo aquí, el escritor brasileño se enfrenta a dos obstáculos que resuelve, sin embargo, con audacia: el primero corresponde a que la comunidad tupí practicaba la poligamia; el segundo, que ello ponía en jaque la idea de una familia estable. Frente al primer fenómeno, el brasileño aduce una "disminución sexual" de la unión polígama, equiparándola a la práctica de carácter patriarcal-hebreo:

[...] la poligamia de los tupís fue de la misma naturaleza que la que existía entre los hebreos; era una poligamia patriarcal, hija de la condiciones de vida salvaje, y no la poligamia sensual de los turcos y otros pueblos del oriente, producida únicamente por el estímulo de la lascivia $(123)^{10}$.

La poligamia se explicaría entonces a partir de las condiciones salvajes mismas, lejos de ser motivada por ansias estrictamente sexuales: la mujer necesitaba hombres que la defendieran. Al tiempo, los guerreros debían propagar su poder a través de una estirpe numerosa, y ello justificaba la elección de más de una compañera. Por otro lado, la familia estable que amenaza con disolverse cuando se ubica lejos de la monogamia, es salvada por el autor al considerar que "la posesión de muchas mujeres no destruía la institución de la familia, bien caracterizada por la primera mujer o verdadera esposa" (123). Entre tanto, como reverso de la contención o la castidad, aparecen los castigos al desenfreno sexual. Y esto, como ya se intuye, posee para el autor una dimensión positiva, en el

\footnotetext{
${ }^{10}$ Nos preguntamos si Alencar no sucumbe en el mismo error esencialista y degradante que critica en los pensadores que estigmatizaron a los tupís, cuando hace lo propio con los "orientales".
} 
marco de su formación religiosa (habría que agregar, violentamente androcéntrica): "la mujer que traía la fe conyugal, o el concubinato, era una adúltera, es decir, una ladrona y descendía hasta la última infamia. El marido tenía el derecho de matarla; el amante la entregaba al desprecio de la tribu" (24).

En medio de tales cavilaciones, el autor recurre a preguntas que, además de afianzar una representación "moralizada" del aborigen (de acuerdo con un ethos cristiano), buscan ponerlo a funcionar como símbolo nacional, y como espacio desde el cual se promueve/ consolida una pretendida "axiología brasileña”: “¿dónde está la sociedad civilizada, que observe leyes tan rigurosas y refrene los instintos sensuales con la severidad usada por los tupís?” (123).

\subsection{Hospitalidad}

Entre las prácticas que humanizan a los indios se encuentra la hospitalidad. Se trata de una de las virtudes “[...] más veneradas entre los indígenas. Todos los cronistas dan testimonio de ella [...]” (138). Será un indicio de su innegable nobleza: "Si hay un rasgo noble del carácter salvaje es esa hospitalidad, que el extranjero no pedía y sí exigía como un derecho sagrado con esta simple forma -Vine, a lo que el dueño de la cabaña respondía-Bienvenido" (139). Igualmente, implicará una equidad en el trato humano, sin la mediación de las relaciones de amistad o enemistad de las tribus. Esta ley "no consentía que se preguntase el nombre al extranjero que llegaba, ni que se indagase su nación tal vez fuese un enemigo; y el huésped no debía encontrar en la cabaña que lo acogía sino paz y amistad" (139). Otros fragmentos de Ubirajara permiten apreciar que el código hospitalario entraña una valoración del huésped, porque enseña o instruye a quienes lo reciben, y porque puede consolidar la fama del que lo acoge. A la par, esta práctica pone de relieve la generosidad del indígena, en tanto comprende ofrendas de comidas y de adolescentes vírgenes. Con las anteriores señalaciones, Alencar destaca en los indios una serie de conductas amables, cariñosas, caritativas. En una palabra, su trabajo literario (y por qué no, etnográfico) intenta pensar al aborigen lejos de cualquier brutalidad animalizante.

\subsection{El honor y la heroicidad del salvaje}

Así como muchas otras tribus, los tupís tenían en alta estima la fuerza guerrera. Una de las conductas más destacables tenía que ver con el honor del prisionero, quien estaba obligado a no huir de su castigo: "el desprecio del enemigo lo acompañaría hasta sus nativos; y la aldea de sus hermanos no se abriría para el fugitivo que hubiese 
deshonrado el nombre de su nación" (47). A su vez, en este marco, es preciso subrayar la exaltación de la sangre o los linajes. Para los indígenas era importante la reproducción sexual que tenía en cuenta criterios como la fuerza y belleza del varón, o la virginidad de la amante. Tales consideraciones conducen al autor a establecer una comparación entre el imaginario tupí y algunos valores medievales:

Las leyes de la caballería, en el tiempo en que esta floreció en Europa, no excedían por cierto en pundonor y bríos a la bizarría de los salvajes brasileños. Jamás el punto de honra fue respetado como entre los bárbaros, que no eran menos gallardos y nobles que esos otros bárbaros, godos, y árabes que fundaron la caballería (131).

Así las cosas, se pone en escena el gesto crítico de un Alencar que busca, en primera instancia, ensalzar a los indígenas. Como se ve, señala los orígenes igualmente bárbaros de los europeos, no para degradar lo bárbaro en sí, sino para atacar la asociación entre ello y términos como "inferioridad" o "atraso". En segunda instancia, el autor pretende cuestionar cierta altivez eurocéntrica. Su obra conduce a repensar los prejuicios sobre los pueblos salvajes, tanto los del viejo como los del nuevo continente. En esta vía, se opone a la idea de que los últimos sean realmente inferiores a los primeros. En tercera instancia, el brasileño se revela como un pensador que sabe articular argumentos basados en el rigor de las lecturas. Como prueba de la auto-representación de la que hablábamos antes, Alencar ofrece una lección de conocimiento histórico a los posibles detractores con los que se enfrenta (o enfrentará) discursivamente.

\subsection{La idoneidad moral del tupí frente a otras tribus}

En diversos momentos, el escritor presenta a la comunidad tupí como un grupo que, entre más fiel permaneció así mismo, sin incorporar costumbres de otras tribus o sociedades, más noble se mantuvo. Esto puede advertirse cuando medita sobre la lealtad de los aborígenes, que disminuye con la llegada de los colonizadores: "fue después de la colonización que los portugueses, asaltándolos como a fieras y cazándolos a cara de perro, les enseñaron la traición que ellos no conocían" (119). La antropofagia, una de las prácticas de las que hablaremos más adelante, también pierde su grandeza, por culpa de los Aimorés: "si en algunas tribus o aldeas indígenas se propagó el apetito depravado, esa degeneración fue probablemente debida al contagio de los Aimorés, cuya invasión es posterior al descubrimiento." (133). Y, sin embargo, la hospitalidad mantiene su fuerza: "es posible que después de la colonización, los salvajes, 
víctimas de las perfidias de los aventureros, relajasen sus tradiciones. Pero la hospitalidad siempre fue cosa sagrada" (139).

Este apartado nos permite pensar que, en Ubirajara, muchos de los colonizadores son duramente criticados. Sin embargo, en los comentarios que el propio autor ha insertado en la novela, se entroniza la moralidad cristiana como verdad suprema. Moralidad que fue impuesta, propagada, en el caso brasileño, por Portugal. De manera que la figura (o la representación) del colonizador oscila, se tensiona, se bifurca problemáticamente, para resultar asociada, en último término, a un proceso civilizatorio redentor.

\subsection{Carne humana}

La antropofagia es uno de los puntos álgidos en el proceso de "humanización" del indígena. Para este propósito, Alencar intenta objetar todas aquellos tesis que han tergiversado la función del canibalismo tupí. Inicialmente, decide operar por negación, estableciendo lo que la antropofagia no es. Lo primero que dirá es que el canibalismo de la tribu no es motivado por el hambre o la gula: "creo que la idea de gula debe ser rechazada sin dudarlo" (133).Tampoco es ferocidad: "por contraprueba debemos excluir la ferocidad como razón del canibalismo americano” (133). Mucho menos venganza: "no era sin embargo la venganza la verdadera razón de la antropofagia. El salvaje no comía el cuerpo del matador de su padre o hijo, se lo mataba en combate [...] la venganza entonces se agotaba con la muerte." (135).

En contrapartida, la virtud de la heroicidad le permitirá legitimar la antropofagia. Ello podemos notarlo cuando asevera que es "una especie de comunión de la carne, por la cual se operaba la transfusión del heroísmo" (35). 0 cuando sostiene que el "sacrificio humano significaba una gloria insigne reservada a los guerreros ilustres o varones egregios cuando caían prisioneros. Para honrarlos los mataban en el marco de la fiesta guerrera" (135). Ahora bien, una de las más creativas formas de entender esta práctica será comparándola con la comunión cristiana ("una especie de comunión de la carne"). Lo anterior revela dos cuestiones importantes: la necesidad de "limpiar" la imagen del indígena, para insertarlo en su empresa de construcción identitaria, y a la vez, el interés de exaltar el cristianismo como referente impostergable. Pero además, hay otra operación tras la cual Alencar ennoblece el acto caníbal: abordándolo desde una perspectiva estética. Estetizar las prácticas las hace válidas, intensas, espirituales de otro modo. 
[...] transportémonos ahora, no como hombres y cristianos sino como artistas, al seno de las selvas seculares, a las tabas de los pueblos guerreros que dominaban la patria salvaje, quién será tan estricto como para negar la fiera nobleza de ese bárbaro y tremendo sacrificio? [...] La idea repugna, pero el banquete salvaje tiene una grandeza que no se encuentra en el festín de los átridas y está bien lejos de inspirar el horror de esa atrocidad, que pese a ello no fue desdeñada por la musa clásica ([sic]136).

Y así, recapitulando, habría una triple justificación en el acto de comerse a otro. La práctica no sólo es avalada porque supone una apreciación del heroísmo, o porque se asemeja (aunque nunca se haría equiparable) a la comunión con Cristo, sino también por su belleza oximorónica, que aúna sorpresivamente nobleza y ferocidad, horror y placer. En esta medida, Alencar elabora parte de su discurso apelando a la experiencia de lo sublime. Más adelante, el escritor lanza una idea concluyente sobre la práctica antropofágica que pareciera guardar los rastros de un "super yo" cargado de cristianismo, e incapaz de admitir del todo el rito caníbal. Esto lo percibimos cuando aclara que "no todas las naciones salvajes eran antropófagas, y en mi opinión, esta costumbre, lejos de ser introducida por la raza tupí, fue recibida por los Aimorés y otros pueblos del mismo origen, que aparecieron en Brasil durante el tiempo del descubrimiento." (136). El enunciado resulta extraño, por los esfuerzos argumentativos que ya mencionados. Como se ve, la obra alencariana sigue desatando preguntas, pese a la claridad ideológica que guardan muchos de sus pasajes.

\subsection{Trascendencia}

Conforme a las investigaciones del escritor brasileño, los tupís no sólo creían en una excelencia superior, sino que hablaban de un genio del mal. También defendían la creencia en la inmortalidad, que se ponía de manifiesto en la forma como adornaban y equipaban a los muertos, para que llegaran en buenas condiciones a los campos alegres. Allí "iban a revivir los guerreros y sus mujeres" (127). Recurriendo a una investigación hecha por Humboldt, Alencar aclara la conexión entre los indígenas y la entidad divina: el hombre se consideraba como la representación de dios en la tierra, es decir, experimentaba a la deidad dentro de sí; por ello, no tenía que edificar estatuas o templos. Como si esto no fuera suficiente, el escritor usará el mismo procedimiento valorativo que efectuó en la dignificación del canibalismo: estetizará la religión, 
abstrayéndola de la moral absoluta en que sólo hay una verdad, la del cristianismo, y tomada de la cuestión desde el punto de vista del arte, no se le puede negar a esta religión tupí, que nivela el hombre a la divinidad, cierto carácter de grandeza salvaje y un vigoroso sentimiento de la individualidad (126).

Por otro lado, la alusión a un "vigoroso sentimiento" individual, concomitante con el auge del romanticismo de la época, podía lograr un efecto de identificación entre los lectores potenciales de Ubirajara y la cultura indígena. No obstante, el fragmento citado sigue estableciendo de forma categórica la diferencia entre una moral absoluta, que contiene la verdad, y otras manifestaciones religiosas, como la de los tupís. Paradójicamente, a partir de tales dicotomías, la exaltación del aborigen se convierte, al tiempo, en un doble elogio hacia la cultura del blanco portugués.

\subsection{Organización política}

De acuerdo con el autor brasileño, otro de los puntos a destacar es la organización política de los indígenas. Esto permitiría pensar en seres humanos con grandes capacidades de resolución de conflictos, dotados de un sentimiento comunitario. "Al igual que la religión, el gobierno de los tupíes era simple, aunque no carecían de este, según proclaman los cronistas; en realidad lo tenían, y bien regulado, para su estado de civilización." (120). Alencar advierte, en este plano, una sociedad civil y una sociedad política: "la primera reducida a la familia y la segunda dedicada exclusivamente a la subsistencia, la defensa y la guerra" (120), estaba representada por la oca o casa; y la segunda, por las tába o reunión de casas. Hasta aquí, todo claro. Sin embargo, el autor brasileño incurre en una extraña homologación cuando, intentando analizar el modelo político tupí desde la teoría política occidental, declara a la comunidad como democrática; inclusive, como practicante del sufragio universal. Así revela que, en más de una ocasión, lee las prácticas de los indios a la luz de un ímpetu anacrónico, deformante. Tal vez las palabras de Lucía Sa (2009) puedan ordenar mejor lo expresado hasta el momento:

Las notas de Ubirajara nos presentan un indio que se porta sexualmente de acuerdo con los patrones cristiano europeos de casamiento y virginidad, que demuestra una religiosidad intensa y monoteísta, aunque peculiar, que mantiene un sistema de gobierno basado al mismo tiempo en la jerarquía patriarcal y en la democracia, y que finalmente, en su ritual aparentemente más repugnante, la antropofagia, no hace nada mas que aproximarse a costumbres cristianas (16). 
Ahora bien, tampoco se trata de negar cualquier coincidencia posible entre los tupís y otros pueblos europeos. Lo que interesa en el ensayo es subrayar que la comprensión del aborigen se hace desde cierta orilla moral y cognoscitiva, impulsada por el afán de fundar una identidad cultural diferenciable y promover un régimen moral. Valga reiterarlo: al tiempo que el escritor engrandece al Otro con un inventario de principios occidentales (curiosa mezcla de valores greco-romanos, medievales y modernos), propone una columna en la que puede levantarse espiritualmente la nación.

\section{El mestizaje ennoblecido o la sagrada compensación}

Nuestra segunda tesis es que en Iracema se representa una colonización ennoblecida por la presencia portuguesa. Así, la obra puede ser leída como fabulación del comienzo de la era cristiana. Este romance indigenista relata la historia de amor entre un portugués llamado Martim Soares y una indígena que lleva el mismo nombre del libro. En el universo diegético propuesto por Alencar, el colonizador encarna la bondad y el respeto. Todas las consideraciones positivas en torno a la figura de este hombre van a tomar una intensidad especial cuando, al final de la obra, el narrador declara que su religión corresponde a la del verdadero Dios. Como en otros casos, el orden moral traído por los europeos queda situado por encima de la espiritualidad tupí: "La palabra del Dios verdadero germinó en la tierra salvaje y el bronce sagrado dobló en los valles" (Alencar, 1944: 157) ${ }^{11}$. Y mientras tanto, resulta sorprendente la imagen del protagonista, depurada de maldad, tal como ha señalado Vagner Camilo (2007). A nuestro juicio, ello evidencia el interés de idealizar la colonización, ya no entendida en términos de violencia, sino de enriquecimiento espiritual:

E o grande peso do compromisso ideológico do romance vai incidir justamente nessa imagem enobrecedora, cortês e heróica, depurada de toda barbárie, do colonizador -seja por se tratar do representante da principal etnia formadora do povo brasileiro, que por isso mesmo necessitava ser sublimada e dignificada, do mesmo modo como se procedeu com o bárbaro íncola sob as vestes do cavaleiro cortês, seja porque visto pela pureza da ótica do índio $(181)^{12}$.

\footnotetext{
${ }^{11}$ Todas las citas de Iracema serán extraídas de Alencar (1944).

12 "Y el gran peso del compromiso ideológico del romance va a incidir justamente en esa imagen ennoblecedora, cortés y heroica, depurada de toda barbarie, del colonizador -sea por tratarse del representante de la principal etnia formadora del pueblo brasileño, que por eso mismo necesitaba ser sublimada y dignificada, del mismo modo como se procedió con el habitante bárbaro ante las vestiduras del
} 
La caracterización de los indios supone otra nobleza innegable (pero secundaria, en este caso), cuyo final discutiremos más adelante. Iracema, primera madre de la nación, es definida a partir de un conjunto de "virtudes". El narrador destacará su amor desmedido por el amante portugués, más allá de que este último aniquile a otros indígenas. Asimismo, la obra resaltará su belleza, coraje y espíritu hospitalario. Por otra parte, Potí, el gran amigo de Martim, es distinguido por su lealtad, gran capacidad reflexiva y talento guerrero. Sin embargo, uno de los momentos en los que el personaje adquiere mayor relevancia es cuando acepta el cristianismo. Desde nuestra perspectiva, tanto la ilimitada entrega de la mujer, como la conversión del hombre, constituyen gestos ideológicos del propio Alencar ${ }^{13}$.

Por lo pronto, con lo que ha sido expuesto, ¿no sería justo declarar que el mestizaje está doblemente beneficiado por el padre y la madre, o en general, por la raza blanca y la india? El escritor brasileño no se olvida de la bondad de los nativos, pero creemos que ésta queda subsumida en una matriz ideológica más grande (eurocéntrica y cristiana), que la supera y la devora. La nobleza aborigen aparece, más bien, bajo la condición de un rastro, de una lumbre a punto de apagarse en la arena del pasado. Si bien Iracema es la progenitora que simboliza toda bondad y sacrificio, tiene que morir, como han subrayado varios críticos literarios, para que el proyecto civilizatorio se instaure ${ }^{14}$. Renato Janine Ribiero se ha expresado críticamente con respecto a este fallecimiento, denunciando cómo la obra de Alencar legítima la presencia europea:

É essa morte que, coincidindo com o nascimento de Moacir, "filho do sofrimento", legitima a ocupação do solo pelo europeu. [...] Nossa história nasce em Martim Soares Moreno e em seu filho... Iracema, a nativa, a mãe,a natureza,fica como lenda (1998, citado por Camilo, 2007: 174) ${ }^{15}$.

caballero cortés, sea porque es visto por la pureza de la óptica del indígena”. (La traducción es nuestra).

${ }^{13}$ El crítico Alfredo Bosi analiza y cuestiona esta sujeción del indígena con respecto al blanco, que aparece en la novela de Alencar. Véase Camilo (2007: 174).

${ }^{14}$ La percepción de Iracema como mito sacrificial que da paso a la cultura blanca ha sido objeto de numerosos debates. A este respeto, se recomiendan dos textos que han fundamentado nuestro ensayo. El de Renato Ribeiro (s/f). "Brasil, el vacío identitario como condición para la acción política”. Y el de Camilo (2007). "Mito e história em Iracema: a recepção crítica mais recente".

15 "Es esa muerte que, coincidiendo con el nacimiento de Moarcir, "hijo del sufrimiento', legitima una ocupación del suelo por el europeo [...] Nuestra historia nace en Martim Soares Moreno y su hijo [...] Iracema, la nativa, la madre, la 
Después de esta cita, conviene hablar finalmente del hijo de Martim e Iracema. Su nombre es Moarcir y representa una raza que crecerá bajo el signo del "Dios verdadero". Es decir, bajo el horizonte que traza su progenitor. Cabe decir que este personaje nace en tierra americana, viaja a Portugal, y por último, regresa al primer espacio, donde se ha venido implantando la cultura de los colonizadores. Precisamente, esta imagen propone "la victoria" de una comunidad "blanca" que expandió su "moral absoluta [...] la del cristianismo" (Alencar, 2009: 126). En el mismo sentido, creemos que el relato contiene las pautas (o el mandato) del "devenir" de la nación: la identidad brasileña tendría que funcionar con los parámetros de la civilización de Martim, es decir, con el conjunto de sus valores, instituciones y esperanzas.

La interpretación que sugerimos intenta visibilizar las relaciones entre literatura e identidad. Podría servir para indagar, más adelante, los nexos entre la escritura de Alencar y el gobierno de Pedro II en Brasil. Este acercamiento ayuda a comprender cómo la literatura va tejiendo una especie de trama de los comienzos (precoloniales y coloniales), con el objeto de marcar las rutas o itinerarios espirituales. En las obras abordadas, se trata de inventar la memoria para explicar/preservar/construir un presente. Pero también para fabricar un futuro que aún no acontece y que, sin embargo, existe bajo la forma de una tarea.

\section{Bibliografía}

Alencar, J. (1944). Iracema. Buenos Aires: Librerías Anaconda. . (2009). Ubirajara. Buenos Aires: Corregidor.

Camilo, V. (2007). "Mito e história em Iracema: a recepção crítica mais recente", Novos Estudos, n 78, CEBRAP, pp. 169-189. Consultado en http://www.scielo.br/scielo.php?script=sci_ arttext\&pid=S0101-33002007000200014

Candido, A. (1981). Formaçao da literatura brasileira: momentos decisivos. Sao Paulo: Itatiaia.

Carrizo, S. (2001). Fronteiras da Imaginaçao: os românticos brasileiros: mestiçagem e naçao. Niterói: EdUFF.

Deckmann Fleck, E. C. (2005). “O nacionalismo de José de Alencar em 'O Jesuíta (1875)' ', Cuadernos del CISH, n 17-18, pp.199213. Consultado en http://www.memoria.fahce.unlp.edu. ar/art_revistas/pr.3602/pr.3602.pdf

Gramuglio, M. T. (2004). "Literatura argentina y literaturas europeas. Aproximaciones a una relación problemática”, Revista del

naturaleza, queda como leyenda". (La traducción es nuestra). 
Centro de Letras Hispanoamericanas, $\mathrm{n}^{\circ}$ 16, CEHELIS, pp 1126.

Marco, V. (1993). “Imágenes de España en la novela histórica de José de Alencar". En Zea, Leopoldo. (Comp.). Historia y cultura en la conciencia brasileña. Ciudad de México: Fondo de Cultura Económica.

Ribeiro, R. J. (s/f)."Brasil, el vacío identitario como condición para la acción política". Consultado en http://www.renatojanine. pro.br/LEstrangeira/identitario.html . (1998). "Iracema ou a fundação do Brasil". En Marcos C. Freitas. Historiografia brasileira em perspectiva. São Paulo: Universidade São Francisco/Contexto. Consultado en http://www.scielo.br/scielo.php?script=sci_arttext\&pi $\mathrm{d}=$ S0101-33002007000200014

Ribeiro Pereira, E. S. (1996). "Um fabulador de nacionalidade. José de Alencar". Sitientibus, n 14, pp. 95-122. Consultado en http://www2.uefs.br/sitientibus/pdf/14/um_fabulador_ da_nacionalidade_jose_de_alencar.pdf

Sa, L. (2009). “Ubirajara: la leyenda y las notas”. En Alencar, José de. Ubirajara. Buenos Aires: Corregidor.

Sánchez-Conejero, C. (s/f). "Pocahontas ataca de nuevo: Iracema o la importancia de la figura del mestizo en la sociedad brasileña actual". Consultado en http:// www.plcs.umassd. edu/docs/plcsfactsandfictions/conejeroreadyforines.doc 
